\title{
The Grand Egyptian Museum and its Role in Achieving Sustainable Tourism in the Memphite Necropolis
}

\author{
Doaa Fathy Ali ${ }^{1}$ \\ Mohamed Zein ${ }^{2}$ \\ Mohammed Heragi ${ }^{2}$ \\ ${ }^{1}$ Egyptian Higher Institute for Tourism- ${ }^{2}$ Faculty of Tourism and Hotels, Luxor Univeristy
}

\begin{abstract}
Egypt is considered as one of the weighty touristic countries in the world. It possesses a cultural and natural heritage that attracts millions of tourists every year. The Egyptian government decided to create a new cultural and heritage attraction which is the Grand Egyptian Museum (GEM) that will house more than 100,000 artifacts from the Pharaonic, Greek and Roman eras and will give a major boost to the tourism sector in Egypt. Announced in 2002, the GEM is believed to be the national Egyptian project of the century as it is one the largest museums in the World displaying the heritage of a single civilization. The Memphite necropolis is a historical place near the GEM and has many archaeological and environmental tourism attractions as well as many traditional handicrafts that form a diversified tourism product. However, there are clearly still shortcomings in this area to be put on the map of sustainable tourism. The existence of the GEM could be a strong motivator for achieving tourism development and finding solutions for the tourism sustainability in the region. The objectives of the study are to indicate the role of the GEM as a global museum on the Egyptian tourism sector.

The paper would find effective tools, with the GEM facilities, for revival and touristic development of important heritage sites in the Memphite Necropolis (specifically the strip from Abu Rawash to Dahshur). It shows the historical relationship between the artifacts of GEM that were discovered at the Memphite necropolis and their places of discovery. In displaying these artifacts and in demonstrating the story behind them, a connection would be created to attract the tourists for visiting their places of discovery (mostly including important pyramids). This would be a tool of upgrading and enhancing the archaeological map of the site for increasing the number of tourists by using the Tourism Routes and Trails starting by the GEM. Besides, the study sheds the light on the other factors of tourist attraction and identifies the problems facing the marketing and the tourism sustainability of the region to develop solution and proposals for it. It also indicates the main principles of tourism sustainability and proposes some means for creating a sustainable tourism in the region that serve the local community without damaging the region's cultural heritage as well as its natural and environmental wealth.

The study relied on a descriptive analytical methodology based on a field study analysis. It describes and analyse the significance of GEM and the historical and archaeological importance of the Memphite Necropolis. It also sheds light on the problems facing the Sustainable Development and the needed Projects: A survey was made by distributing a random sample for tour guides, academic members in faculties and institutes of tourism and hotels, tourist experts, workers in ministry of tourism and antiquities as well as secondary data. The study concluded the necessity of sustaining these world heritage sites, completing and improving its services, making a good marketing plan for it, and including it in the tourist itineraries as main places for visits. Finally, it recommends some additional cultural, educational, entertaining, touristic, building, and economic projects for creating new motivations for the tourist attraction and more chances for a sustainable tourism.
\end{abstract}

Keywords: GEM, Tourism Routes, Cultural heritage, Memphite Necropolis, Itineraries, Sustainable Tourism. 


\section{Introduction}

Sustainable tourism in its various dimensions is considered as one of the essential patterns of tourism in supporting the principle of tourism responsibility. Recently, Egypt strives to implement the principle of sustainability in all fields, especially in the tourism sector. Egypt presents a unique worldwide experience by establishing the Grand Egyptian Museum (GEM), which is one of the international centers for the communication between civilizations. The museum occupied a significant location near the great Pyramid of Giza, one the seven wonders of the ancient world. It is located in the west of Cairo, covering an area of 117 acres and can receive 5 million visitors per year. ${ }^{1}$ Just a few $\mathrm{km}$ from the museum, there is one of the oldest and most significant archeological sites in Egypt which is the Memphite Necropolis. This large area has almost entirely been classified by UNESCO as a "World Heritage Site" and identified as "Memphis and its necropolis with the Pyramids Field". ${ }^{2}$ It extends from Abu Rawash in the north and passes by the pyramids of Giza, Zawiyat al-'Aryan, Abusir, Abu Ghrab, Northern Saqqara, Southern Saqqara, Dahshur, and reached to Meidum in Beni Suef Governorate. ${ }^{3}$ Our study is focusing only on the area from Abu Rawash on the north of Giza to Dahshur on the south. The GEM and the surrounding archaeological sites can be a great tool of touristic development through planning and achieving the sustainable tourism on this region to benefit from its heritage and to take full advantage of its potentials.

\section{Literature review}

\section{Tourism Route and Sustainable Tourism}

Linking the museum artifacts with their places of discoveries via the technology of virtual reality would increase the possibility of using the museum as a tourism route tool for visiting the nearby archaeological sites in the Memphite Necropolis and achieving touristic sustainability in it. The connection of the GEM with the other neighboring site appears in the $2 \mathrm{~km}$ corridor that connects it with the pyramids area, ${ }^{4}$ where the trip begins with the GEM then the visit of Giza with its memorial pyramids. Therefore, we must indicate the importance of the Tourism Routes and the Sustainable Tourism:

- Tourism Route and Trail: ${ }^{5}$ this is one of the tourism aspects that forms a series of places that are connected in high consistency and a specific period. It saves the tourist effort and gives him full knowledge about the monuments and history of this period. ${ }^{6}$ Tourism routs depend on the direct engagement with local communities by providing new job opportunities, increasing income, and developing infrastructure, which positively affects economically the local communities and the sustainability of tourism in these engaged regions. It also contributes in achieving many benefits for the tourist destination including improving its image, highlighting its cultural identity and preserving its heritage, achieving urban development on the tourist route and increasing its tourism services. Through this kind of tourism, a tourist product and new sites are

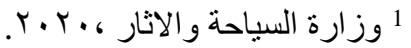

Decision Code: CONF 003 IX; See in https://whc.unesco.org/en/soc/1809 in 10/1/2020. ${ }^{2}$

Edwards I. E. S., The Pyramids of Egypt, Penguin Books, 1993 p. 97-100. ${ }^{3}$

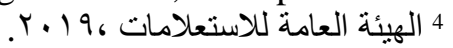

For more about this type of tourism see; Ward-Perkins, D., Beckmann, C. \& Ellis, J., Tourism Routes 5 and Trails: Theory and Practice, CABI, 2019; Timothy, D.J. \& Boyd, S.W, Tourism and Trails: Cultural, Ecological and Management Issues, Channel View Publications, 2015.

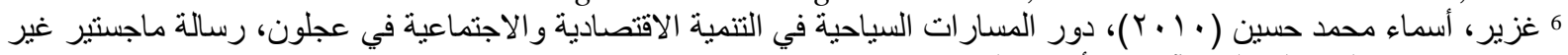

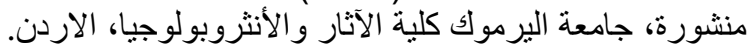


introduced, other than those gets used by the tourist groups, to extend the tourist nights and raise his level of spending. ${ }^{7}$ This kind of tourism can find a great success in the Memphis Necropolis.

- Sustainable Tourism: the various concepts of sustainable tourism emphasize the environmental, social, and economic aspects of tourism to achieve a rational balance of natural resources. ${ }^{8}$ Sustainable Tourism is considered also as the first step in planning any development strategies to the regions or destinations. ${ }^{9}$ It is a complex system containing a set of programs and elements that interact together in an organized and dynamic method to achieve a set of goals. For that, the local communities, and groups as well as the touristic companies should establish coordination mechanism with the responsible ministries to achieve the goals of sustainable Tourism development. ${ }^{10}$ The Egyptian government must start to apply the requirements of sustainability in studied region in order to increase the numbers of tourists.

Sustainable tourism has become one of the lifestyles that push tourists to choose travel offers that provide values for preserving the environment, culture, social life of the local community. ${ }^{11}$ It is also based on a process of learning, culture, and education for optimizing the use of touristic sites. Dealing with the touristic sites consciously and responsibly and managing all available resources, whether social, natural, or economic help in achieving maximum benefit from the heritage and the cultural available data while preserving environmental balance and biological diversity. ${ }^{12}$ Among the essential features of sustainable tourism:

- Quality: sustainable tourism provides a unique experience for visitors as it protects the environment and improves the quality of lifestyle to the host community.

- Balance: sustainable tourism is based on a balance between the needs of the local community, the tourism industry, environmentalists, and tourist destinations.

- Continuity: sustainable tourism guarantees the satisfied experience for the tourist, as well as the continuity of available resources and the culture of the host community. ${ }^{13}$

The sustainability of tourism, when applied, has three aspects that bring benefits to society through the following as indicated in Table No. (1): ${ }^{14}$

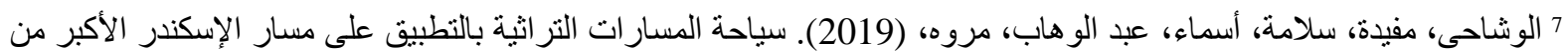

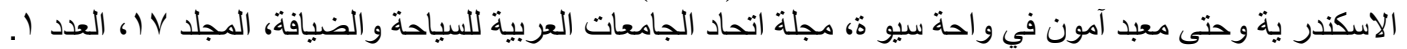

Tolvanen, A. Rämet. J. Kinnunen, I. \& others, Sustainable Tourism, Finnish Forest Research Institute, ${ }^{8}$ Muhos Research Station, Kirkkosaarentie 7, FIN-91500 Muhos, Finland. 2005, p. 2 available online at: https://www.researchgate.net/publication/292146686.

John J. Pigram, Wahab, s., Tourism, Development and Growth: The Challenge of Sustainability, ${ }^{9}$ Routledge, 2005, p. 6.

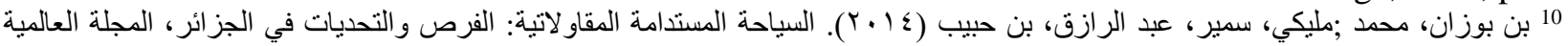
للتسويق الإسلامي.

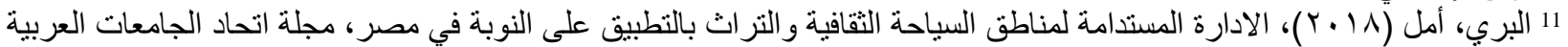

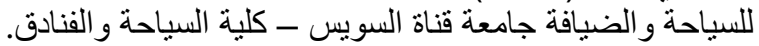

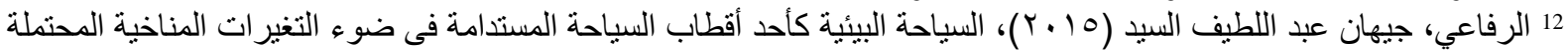

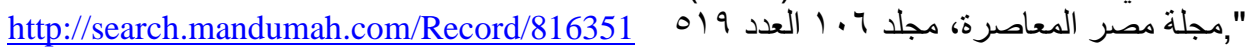

Yazdi, Khoshnevis S., "Sustainable Tourism” in American International Journal of Social Science Vol. ${ }^{13}$

51. .1 No 1, 2012, p

بن بوز ان، محمد ;مليكي، سمير، عبد الرازق، بن حبيب (ع ا ـ ب). السياحة المستدامة و المقاو لاتية : الفرص و التحديات في الجزائر ، المجلة العالمية للتسويق الإسلامي. مليكي 
Table 1: the aspect of sustainable tourism

\begin{tabular}{|c|c|c|}
\hline Environmental sustainability & Economic sustainability & Social sustainability \\
\hline $\begin{array}{l}\text { Establishing controls for } \\
\text { behavioral rationalization } \\
\text { of resource consumption. } \\
\text { - Preserving the } \\
\text { environmental balance. }\end{array}$ & $\begin{array}{l}\text { Attracting new } \\
\text { investments. } \\
\text { - Diversifying the sources of } \\
\text { national income and } \\
\text { economic return. } \\
\text { - Improving infrastructure. }\end{array}$ & 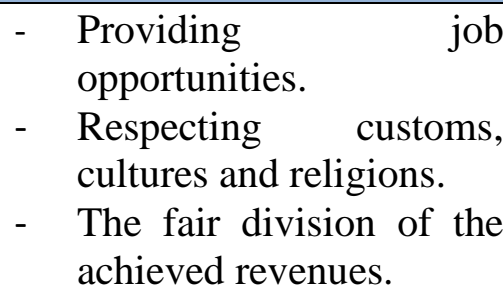 \\
\hline
\end{tabular}

Historical and Archaeological Importance of the Memphite Necropolis

The Memphite necropolis is an ancient Egyptian necropolis located around the city of Memphis, the first capital of ancient Egypt. It includes many sites like; Giza, Saqqara, Abusir, Abu Rwash and Dahshur. This "World Heritage Site" has most of the pyramids of the Old Kingdom were built along with many mastabas and other tombs around the ancient capital of Egypt Memphis. ${ }^{15}$ These sites are near the GEM and some of their artifacts will be displayed in the museum.

1- Memphis: ${ }^{\mathbf{1 6}}$ it was founded in $3100 \mathrm{BC}$, the ancient city is located $20 \mathrm{~km}$ south of Cairo, on the west bank of the Nile. The modern town now is called Mit Rahina. Memphis has several names during its history of almost four millennia. Its Ancient Egyptian name was Ineb Hedj "the white walls". The name "Memphis" was the Greek adaptation of the name Mn-nfr, which was originally the name of the pyramid of Pepi I, located west of the city.

Within the open-air museum in Memphis is a giant colossus of Ramesses II carved of limestone, about 10 meters in length. It was discovered in 1820 near the southern gate of the temple of Ptah by Italian archaeologist Giovanni Caviglia. ${ }^{17}$ Because the base and feet of the sculpture are broken off from the rest of the body, the beauty of this statue lies in its flawless detail of the complex and subtle forms of human anatomy.

In the Grand Egyptian Museum (GEM) is the second colossus which was found in the same year at Memphis also by Caviglia and was restored in the 1950s to its full standing height of 11 meters then was moved in 2006 to Giza due to be exhibited at the entrance Hall of the GEM. The statue is weighing about 80 tons. It impresses the visitors with its huge size and delicate details showing one of the masterpieces of the ancient Egyptian sculpture.

2- Giza: the grand Egyptian Museum is just $2 \mathrm{~km}$ north of the three pyramids of Giza which is ranked as one of the best-known monuments in the world. The massive structures stand as testaments to the engineering skills of the $4^{\text {th }}$ Dyansty kings in ancient Egypt. ${ }^{18}$

The Great pyramid of Khufu (Cheops) is the largest one in Egypt and the only one of the ancient Seven Wonders of the World that still survives. ${ }^{19}$ The Great Pyramid was the highest construction in the world for more than 3,800 years and yet, despite overt hose four thousand years of study, some debate still surrounds the structure at the most basic levels.

\footnotetext{
${ }^{15}$ UNESCO publications, “World Heritage Sites: A Complete Guide to 878 UNESCO World Heritage Sites”, Firefly Books, 2009, p. 70.

${ }^{16}$ http://www.antiquities.gov.eg/DefaultAr/WorldHeritageSite/Pages/WorldHeritage.aspx?WorldHeritageCode=7 David D. Peck, Voyage without a Harbor, iUniverse, 2014, p. $25 .{ }^{17}$ Fagan, M.B., The Oxford Companion to Archaeology, New York : Oxford University Press, 2012, p. ${ }^{18}$ 583. Hellum, J. E., The Pyramids, Greenwood Press, 2007, p. 84, 85. ${ }^{19}$
} 
The only statue carries the features of that great king Khufu is made out of ivory and will be displayed at the GEM with the treasure of queen Hetepheres, his mother. This tresure was found next to his pyramid and already started to be exhibited in a modern technology way in GEM.

The biggest boat in the ancient word was discovered near the great pyramid, it is a mythical ship to help king Khufu in his journey to the next word, ${ }^{20}$ it is now preserved in the solar boat museum beside the great pyramid and will move to join the GEM's collection.

The second largest pyramid is for king Khafra (Chephren) and the smallest one belongs to Mnkawra (Mycarinous). The sphinx is the legendary guardian that stands by the huge funeral complex with its lion body and the head of king Chephren. Next to the sphinx is the Valley Temple, the place where the priests mummified the dead body of King Chephren. The diorite statue of Khafra and the traids of Mnkawra in GEM witness of the greatness of the ancient Egyptian sculpture during the time of the pyramids' builders.

3- Abu Rawash: it is located $8 \mathrm{~km}$ north of Giza plateau. It has unfinished pyramid called the lost pyramid of king Djedefre son of Khufu, the Archaeological site is a cemetery since $1^{\text {st }}$ dynasty. In July 2012, a funerary wooden boat discovered at Abu Rawash, it is the oldest boat ever found in Egypt and the whole world as it dates to the reign of king Den (c. 2950 BC), thus it is 400 years older the than the famous solar boat of Khufu. The two ancient boats will be exhibited in the Grand Egyptian Museum (GEM) to expand our knowledge of shipbuilding techniques in the early times of Egypt. ${ }^{21}$

4- Abusir: it is located in the western bank of the Nile river, North of Saqqara, only $25 \mathrm{~km}$ south west of Cairo. ${ }^{22}$ Abusir is one relatively small segment of the extensive "pyramid field" that extends from north of Giza to the south of Saqqara. Name of Ausir is the Arabic pronunciation for the Egyptian name "pr wsjr" the House of Osiris. Abusir also called royal necropolis of the forgotten kings of the $5^{\text {th }}$ Dynasty. These kings do not have the fame and number of tourists that of their predecessors of the $4^{\text {th }}$ Dynasty. The 14 pyramids discovered there are built of low quality local stone. The three major pyramids of visits at the site are the tallest pyramid which belongs to king Neferirkare Kakai, ${ }^{23}$ then, Pyramid of Niuserre which is the most intact pyramid and Pyramid of Sahure known for its finely carved reliefs. ${ }^{24}$ There is also the sun temples like that of king Userkaf. ${ }^{25}$ Abusir also was the origin of the largest find of Old Kingdom papyri scattered in many museums. ${ }^{26}$

5- Saqqara: ${ }^{27}$ one of the rare places in Egypt that has monuments from predynastic time until Greco-Roman period and one of these monuments is the so-called "philosophies circle". ${ }^{28}$ At

Verner, M., The pyramids, Atlantic Books Ltd, 2014, p. 30- 40; Jenkins, N., The boat beneath the ${ }^{20}$ pyramid: King Cheops' royal ship, Holt, Rinehart and Winston, 1980, p. 8. https://www.mq.edu.au/research-impact/2014/09/04/the-earliest-funerary-boat-ever-found/21 Elweshahy M. \& ElGammal I., Sustainable Tourism Planning in the Area of Abusir, JAAUTH vol $9^{22}$ (2012), p. 13-27. Verner, M., The Pyramids: The Mystery, Culture, and Science of Egypt's Great Monuments, Grove ${ }^{23}$ Press. 2001 p. 291-297 \& 311-319. Ibid, p.280-290. ${ }^{24}$ Ibid, p.267. ${ }^{25}$

The Czech Institute of Egyptology of the Faculty of Arts, Charles University in Prague has ${ }^{26}$ been conducting excavations at Abusir since 1976.

${ }^{27}$ For further information see; Lauer J. Ph., Saqqara: the royal cemetery of Memphis : excavations and discoveries since 1850, London: Thames and Hudson, 1976. River, C., Saqqara: The History and Legacy of the Ancient Egyptian Necropolis Near Memphis, CreateSpace Independent Publishing Platform, 2018. 
Saqqara, the world's oldest large-scale stone monument known in history was built which is Djoser's step pyramid complex, during the $3^{\text {rd }}$ Dynasty. ${ }^{29}$ It was an innovation idea by the smart architect Imhotep. The first Pharaonic life size statue of Djoser discovered at Saqqara ${ }^{30}$ and will ornamented the Great Gallery of the GEM with 100 Great Egyptian kings.

Another sixteen Egyptian kings built pyramids at Saqqara, which are now in various states of preservation or collapse. For example the pyramids of the kings Unas and Teti of $5^{\text {th }}$ and $6^{\text {th }}$ dynasty, which have the first appearance of pyramid texts on the walls of their burial chambers, designed to protect the dead king's passage into the afterlife. ${ }^{31}$ Saqqara remained an important complex for non-royal burials as well; like mastaba of Hesira, $3^{\text {rd }}$ dynasty, in GEM will exhibited the great group wooden panels of Hesira represented his achievements during the course of his life as the oldest example of the advanced wooden sculpture in ancient Egypt. ${ }^{32}$

6- Dahshour: ${ }^{33}$ it is an ancient royal necropolis located roughly $30 \mathrm{~km}$ south of Cairo. It is marked by two distinctly oldest "true" pyramids belong to king Sneferu the founder of the $4^{\text {th }}$ dynasty: the older one is referred to as "Rhomboidal" or "Bent" pyramid (2613 BC) is a fine example of possibly the original method of construction with its mistakes to build a smooth sided pyramid instead of a step pyramid. ${ }^{34}$ The second is the "Red Pyramid" (2589 BC) which was the first "true" smooth-sided pyramid ever built. ${ }^{35}$ There is also the Black Pyramid of King Amenemhat III which remains a popular tourist attraction even though it is unfinished one and now severely damaged. The Potentials of tourist attractions in the area (Memphite Necropolis) are shown in table no.(2)

Table 2: The Potentials of Tourist Attractions in the Memphite Necropolis

\begin{tabular}{|c|c|}
\hline \multicolumn{2}{|r|}{ Various Potentials } \\
\hline $\begin{array}{l}\text { Location and } \\
\text { Climate }\end{array}$ & $\begin{array}{l}\text { The area of the Memphite Necropolis is characterized by its privileged location and } \\
\text { proximity to Cairo, west of the Nile River and the continental climate, where } \\
\text { temperatures generally rise during the summer and fall during the winter months, so } \\
\text { the annual temperature range is relatively high. }{ }^{36}\end{array}$ \\
\hline $\begin{array}{l}\text { El Hassana } \\
\text { Dome } \\
\text { Protectorate }\end{array}$ & $\begin{array}{l}\text { Announced in 1989, El Hassana Dome Protectorate is in the Giza governorate and } \\
\text { covers a land area of one square km, just } 23 \mathrm{~km} \text { from Cairo. It is located on the Cairo- } \\
\text { Alexandria road at Abu Rawash and lies around } 8 \mathrm{~km} \text { from the Great Giza Pyramids. } \\
\text { The distinguished history of the reserve is depicted in its topographical merits and its } \\
\text { geological makeup. El Hassana dome is the only reserve near Cairo that has remnants } \\
\text { from the crustaceous age dating back to about one million years. The rocks found } \\
\text { here belong to the Stone Age and are believed to have been formed } 60 \text { million years }\end{array}$ \\
\hline
\end{tabular}

It is a monument to important Greek thinkers and poets, consisting of statues of Hesiod, Homer, Pindar, ${ }^{28}$ Plato, and others (Ptolemaeic).

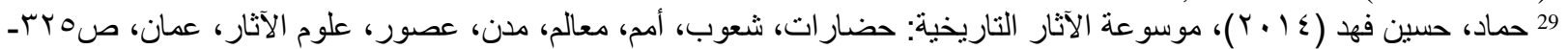
rTY

El-Shahawy, A., \& Mathaf al-Mișri, M., The Egyptian Museum in Cairo, American Univ in Cairo Press, ${ }^{30}$ 2005, p. 17.

Shaw, I., The Oxford History of Ancient Egypt, Oxford University Press: Oxford, 2000, p. 102- 104. ${ }^{31}$ Robins, G., The Art of Ancient Egypt, Harvard University Press, 2008, p.51. ${ }^{32}$ ${ }^{33} \mathrm{http://www.tda.gov.eg/TdaRegions/EgyMap.aspx} \mathrm{in} \mathrm{9/5/2020}$

Andreu-Lanoe G., Egypt in the Age of the Pyramids,trans. From French by David Lorton, new York: ${ }^{34}$ Cornell university press 1997. Shaw, I. \& Nicholson P., A British Museum Dictionary of Ancient Egypt, London: 1995. ${ }^{35}$

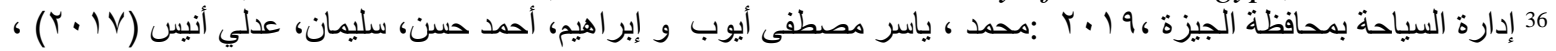

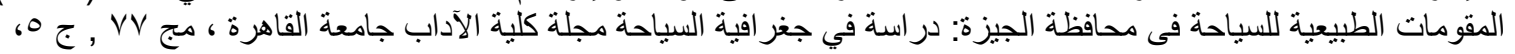
http://search.mandumah.com/Record/846416 


\begin{tabular}{|c|c|}
\hline & $\begin{array}{l}\text { back and from the rocky age about } 40 \text { million years back. It is considered an open } \\
\text { museum that shows the full history of its ancient life, environment and climate during } \\
\text { the upper Cretaceous era. }{ }^{37} \text { It is considered an open museum that shows the complete } \\
\text { record of its ancient life, environment and climate during the upper Cretaceous } \\
\text { period, a geological reserve characterized by a complex geological structure known } \\
\text { as the composition of Abu Rawash and has a scientific significance for those } \\
\text { interested in geology. This nature reserve is also unique to the growth of the } \\
\text { Selakpakua plant, which are dwarf trees with wooden logs. } .^{38}\end{array}$ \\
\hline $\begin{array}{l}\text { Desert } \\
\text { Environment }\end{array}$ & $\begin{array}{l}\text { It possesses an amazing nature with dry valleys and plateaus such as at Giza and Abu } \\
\text { Rawash Plateau. One of the important characteristic of the region is the phenomenon } \\
\text { of the emergence of crocodiles, which qualifies them for the pattern of scientific and } \\
\text { geological tourism }\end{array}$ \\
\hline $\begin{array}{l}\text { Rural } \\
\text { Environment }\end{array}$ & $\begin{array}{l}\text { Dahshur, Abruash and Abusir contain different cultivated lands and green spaces that } \\
\text { qualify them to take advantage of the Rural Tourism. Tourists can actively participate } \\
\text { in a simple rural lifestyle in many of small villages in the region with the help of the } \\
\text { hospitable and eager villagers of the local community. }\end{array}$ \\
\hline $\begin{array}{l}\text { Seasonal Lake } \\
\text { of Dahshur }\end{array}$ & $\begin{array}{l}\text { The water level of the lack increases from October to December, }{ }^{40} \text { attracting different } \\
\text { species of birds from all over the world. Therefore, migratory birds can be seen in the } \\
\text { region at this period. This makes the region a tourist destination for bird watching. }\end{array}$ \\
\hline Monuments & $\begin{array}{l}\text { A big number of monuments, dating back to different eras, in this region such as Giza } \\
\text { Pyramids and the sphinx, Saqqara with its Step Pyramid, Abu Rawash, Abusir with a } \\
\text { number of tomb and Pyramids, Dahshur Pyramids. }\end{array}$ \\
\hline $\begin{array}{l}\text { Industries and } \\
\text { Handicrafts }\end{array}$ & $\begin{array}{l}\text { - There are many papyrus workshops especially in Giza. } \\
\text { - Al Harraniya Village is known for the manufacture of carpets and kilims that } \\
\text { passed on from a generation to generation. } \\
\text { - It has oldest handicraft workshop based on palm trees. Local people get a fame of } \\
\text { manufacture cages, chairs, and tables and other products made of palm leaf. } \\
\text { - Harraniya Modern Art School for batik wall tapestry and ceramic wall hanging. }{ }^{41} \\
\text { - Association of New heritage handicrafts in Dahshur in which a group of women } \\
\text { from the local community performs some traditional handicrafts such as "carpets } \\
\text { and mats" using high-quality environmental resources. }{ }^{42}\end{array}$ \\
\hline $\begin{array}{l}\text { Accommodation } \\
\text { and food } \\
\text { preparation } \\
\text { services }\end{array}$ & Giza Governorate has 13 five-star hotels, 7 four-star hotels, 21 three-star hotels. ${ }^{43}$ \\
\hline
\end{tabular}

Problems Facing the Sustainable Development and the Needed Projects: Common problems affecting the region's tourism sustainability are as following:

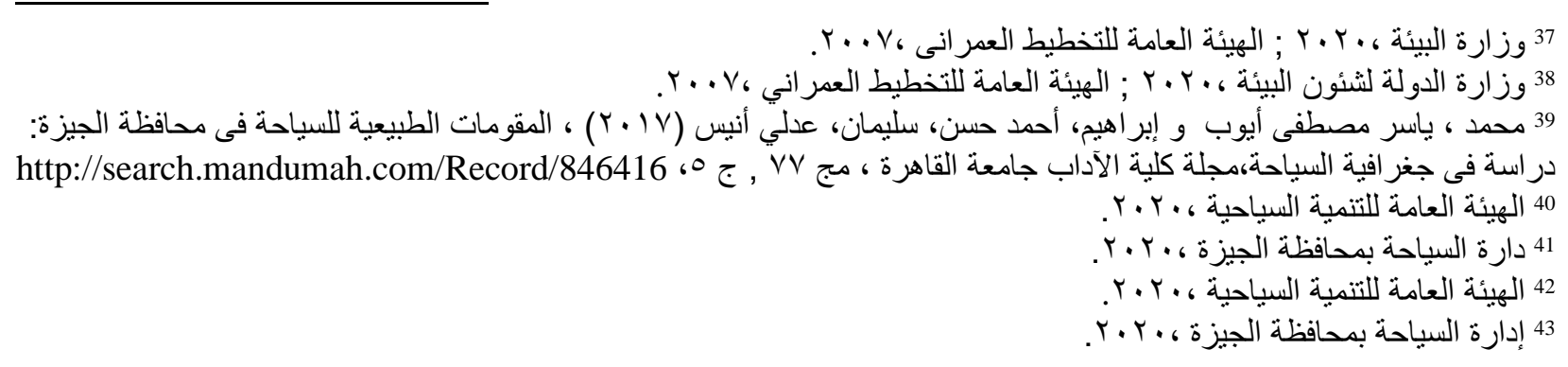


- Urban encroachment in the areas of Abu Rawash, Abusir and Dahshur, which prompted the governorate to undertake some measures to protect the cultivated areas as a result of urban sprawl.

- Lack of infrastructure at the regional level such as water and sewage networks.

- Accumulation of garbage in the majority of streets, existence of horse stables nearby the residential blocks, and pollution of waterways are negative factors upon the tourism attraction.

- Lack of awareness among the local population about the importance of tourism and environment in the region. In some touristic sits, there is a harassment of tourists by overly and aggressively vendors which affects greatly upon the desire of tourists to return.

- Disappearance of heritage handicrafts and shortage of marketing policies for these products lead the handicraft workers to leave in favor of other professions. ${ }^{44}$

\section{The main sustainable development projects in the region:}

\section{Services and infrastructure:}

- Rehabilitation of all asphalt roads and movement tracks inside and outside the Giza plateau, implementation of an electronic portal at the entrance of the archaeological site from the intersection of Al Haram Street and the construction of a concrete road leading to the temple of Sphinx.

- Implementing limestone fences to determine movement paths, implementing a continuous barrier of chains around the three pyramids and paving the parking area in front of the Great Pyramid. $^{45}$

\section{Awareness and education for residents and tourists}

- Contracting with one of the specialized companies for cleaning the area continuously.

- Constructing information cabins with wooden pergolas to provide the services of the Tourism Promotion Authority.

- Developing the Sphinx entrance yard, evacuating street vendors and putting a set of informative signs and illustrative maps.

- Making fixed umbrellas for individuals and cars to avoid weather factors.

- Converting the Giza plateau to an open museum and contacting it with the Nile branches (Mansourieh Canal).

\section{Tourist and hotel services}

- Establishing hotels area in the north of the GEM and northeast of the Mena House Hotel.

- Making tourism services down to the pyramids plateau on Mansuriyya axis at the southern entrance to the Sphinx area and the main entrance (the Khufu axis).

- Expanding the view of the region, seeing it from distant areas and clarifying its borders to ensure that it is not encroached upon.

- Linking the GEM and the studied areas at the Memphite Necropolis via pedestrian tracks. ${ }^{46}$

\footnotetext{
44 إمام، حسن فهم، مر اد، رضوى محمود حافظ (بدون سنة نشر)، أنوية التجمعات السياحية المنغلقة والتأثير المنوقع على المدى المرئى على التنمية المستدامة لمنطقة سقارة.

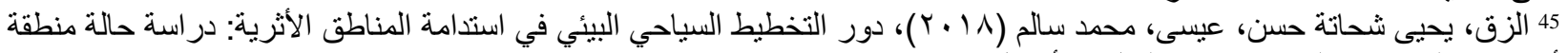

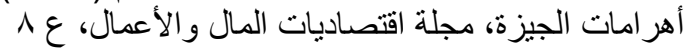


- Activating industries and handicrafts inside the region and establishing many tourism projects that do not affect the nature of the place.

- Preserving the architectural heritage and the environmental dimension of the place.

The field study questionnaire is mainly based on literature reviews of Al-Rifai, ${ }^{47}$ Thuraya,${ }^{48}$ Ben Bouzban $^{49}$ and others andAl-Zaq and others ${ }^{50}$. The study of Al-Rifai referred to the importance of the sustainable tourism in achieving the development of remote areas, promoting loyalty and belonging of common people, appreciating and protecting the national heritage, preserving the environment and natural resources, as well as distributing development processes more equitably to different regions. In her study, Thuraya also indicates that achieving sustainable tourism development requires a set of procedures and principles that will successfully harmonize the activity and desires of the tourist on the one hand and protect environmental resources and social systems and maximize economic benefits on the other hand. This will be through enacting of laws and legislations related to the protection of environment, limiting the absorptive capacity of tourist sites and spreading tourism awareness and environmental culture among the local population. This will be through encouragement of making projects that provide an income to the local population from handcraft and traditional industries and their role as local tour guides. The study of Ben Bouzban and others and Rabeaa and Ahron showed the main characteristics and benefits that sustainable tourism achieves in terms of economic, social, cultural and environmental aspects, as well as the study of Al-Zaq and others that dealt with the role of environmental tourism planning in the sustainability of archaeological areas: a case study of Giza Pyramids area and the important obstacles in the region.

\section{Field Study}

A questionnaire consisting of three axes was made in which the first axis included 7 statements about the availability of the requirements to achieve sustainable tourism development in the Memphite Necropolis. The second axis contained 16 statements related to the benefits of achieving sustainable tourism development by using the GEM as a route to the Memphite Necropolis. The third axis contains 7 statements about the obstacles facing the achievement of tourism sustainability in the Necropolis. The questionnaire contained also a question for the investigators about their proposals to achieve sustainable development in the region.

The five-level Likert scale was used in the study. The responses were varied (5 Strongly Agree or Strongly Available, 4 Agree or Available, 3 Somewhat Agree or Somewhat Available, 2 Unavailable or Disagree, 1 not available at all or disagree at all). A number of 125 questionnaires were distributed to tour guides, academic members in faculties and institutes of tourism and hotels, tourist experts, workers in Ministry of Tourism and Antiquities. The number of valid survey forms was 10 which is $82.4 \%$ of the total number .A number of 22 invalid forms were excluded.

\section{Data and results analysis}

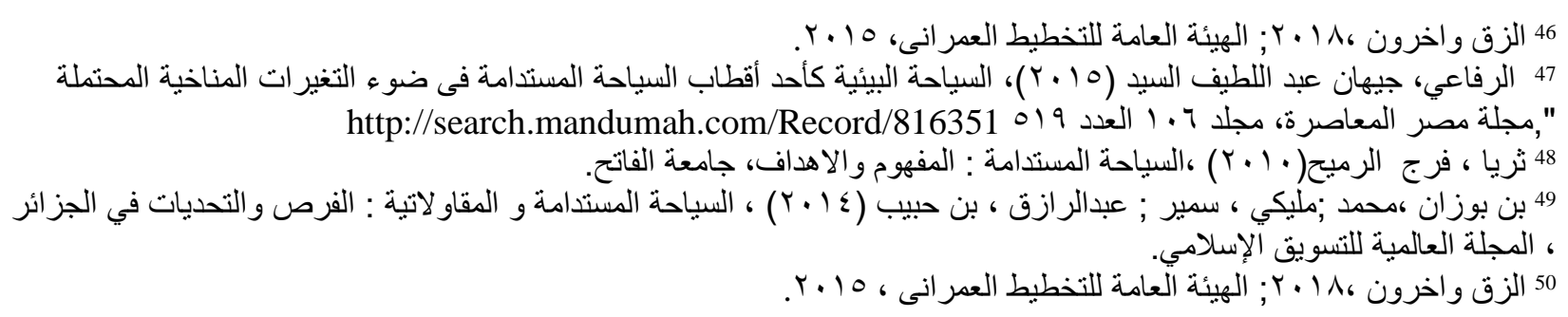


Statistical analysis software (SPSS Statistics V22) was used for interactive data analysis, extraction of frequencies, percentages, means, standard deviation and difference coefficient as well as statistical correlation between variables using the correlation coefficient.

\section{Results and discussion}

\section{Stability test and internal validity of study's vocabulary (Cronbach's alpha): ${ }^{51}$}

To verify the validity and consistency of the study sample, the Cronbach's alpha was used to measure the internal correlation of variables of the used study. The results showed that its value ranges between $(0.667-0.944)$ which is statistically acceptable as shown in the table 3 .

Table (3): Cronbach's alph

\begin{tabular}{|c|c|c|}
\hline Axes/ Items & Cronbach's Alpha & N of Items \\
\hline First Axis & 0.667 & 7 \\
\hline Second Axis & 0.944 & 14 \\
\hline Third Axis & 0.884 & 7 \\
\hline
\end{tabular}

\section{Descriptive Analysis of Results}

Table (4): analyses the results about the availability of the requirements for achieving sustainable tourism

development in the Memphite Necropolis.

\begin{tabular}{|l|c|c|c|c|c|c|c|c|}
\hline \multicolumn{1}{|c|}{ Item } & $\begin{array}{c}\text { strongly } \\
\text { available }\end{array}$ & Available & $\begin{array}{c}\text { somewhat } \\
\text { available }\end{array}$ & $\begin{array}{c}\text { Not } \\
\text { available }\end{array}$ & $\begin{array}{c}\text { not } \\
\text { available } \\
\text { at all }\end{array}$ & Mean & $\begin{array}{c}\text { Std. } \\
\text { Deviation }\end{array}$ & $\begin{array}{c}\text { Coefficient } \\
\text { of } \\
\text { variation } \\
\text { c.v.\% }\end{array}$ \\
\hline $\begin{array}{l}\text { Community participation } \\
\text { in the development } \\
\text { process }\end{array}$ & 2 & 23 & 36 & 38 & 4 & 2.82 & .894 & .317 \\
\hline $\begin{array}{l}\text { Visitor centers to provide } \\
\text { information in the area }\end{array}$ & - & 23 & 43 & 35 & 2 & 2.84 & .789 & .277 \\
\hline $\begin{array}{l}\text { Good management of } \\
\text { natural and human } \\
\text { resources }\end{array}$ & - & 27 & 49 & 27 & - & 3.00 & .728 & .242 \\
\hline $\begin{array}{l}\text { Maintaining the high } \\
\text { degree of tourist } \\
\text { satisfaction }\end{array}$ & 6 & 40 & 40 & 15 & 2 & 3.32 & .866 & .260 \\
\hline $\begin{array}{l}\text { Environment-al awareness } \\
\text { and education for the } \\
\text { tourist and the local } \\
\text { community. }\end{array}$ & 2 & 24 & 41 & 31 & 5 & 2.87 & 0.893 & .311 \\
\hline $\begin{array}{l}\text { Promotion and marketing } \\
\text { for sustainable tourism } \\
\text { practices }\end{array}$ & 2 & 23 & 38 & 35 & 5 & 2.83 & .901 & .318 \\
\hline $\begin{array}{l}\text { Considering the absorptive } \\
\text { capacity of the place }\end{array}$ & 1 & 43 & 27 & 21 & 4 & 3.29 & 1.006 & .305 \\
\hline
\end{tabular}

Table (4) concerns the first axis and indicates the availability of the requirements to achieve sustainable tourism development in the Memphite Necropolis. The views of the study sample indicated that there is a participation of the local community in the development process and existence of visitors' centers providing information about the region. There is also a good administration for natural and human resources as well as environmental awareness and

\footnotetext{
${ }^{51}$ Cronbach's alpha is a measure used to assess the reliability, or internal consistency, of a set of scale or test items. In other words, the reliability of any given measurement refers to the extent to which it is a consistent measure of a concept, and Cronbach's alpha is one way of measuring the strength of that consistency.
} 
education for the tourist and the local community. The promotion and marketing of sustainable tourism practices are available to some extent with an average rating value between (2.82 -2.87) with a standard deviation whose value ranges between (0.894- 0.901). The values of the standard deviation and the coefficient of variation are less than half of the mean value, and this indicates that there is no dispersion in the data, because it is less than half of the mean value.

The views of the respondents also indicate that there is a preservation of the high degree of tourist satisfaction and consideration for the absorptive capacity of the touristic place. This is with an arithmetic mean whose value ranges between (3.29 - 3.32) and a standard deviation whose value ranges between (866 1.006). Therefore, the values of the standard deviation and the coefficient of variation indicate no dispersion in the data, because it is less than half the value of the arithmetic average.

Table (5): Results regarding the benefits that would be achieved by the development of sustainable tourism and the use of the GEM

\begin{tabular}{|c|c|c|c|c|c|c|c|c|}
\hline Item & SA & A & $\mathrm{N}$ & $\mathrm{D}$ & SD & Mean & $\begin{array}{c}\text { Std. } \\
\text { Deviation }\end{array}$ & $\begin{array}{l}\text { Coefficient of } \\
\text { variation c.v\%. }\end{array}$ \\
\hline \multicolumn{9}{|l|}{ Economic aspects } \\
\hline Diversification of income sources & 52 & 41 & 6 & 4 & & 4.37 & .767 & .175 \\
\hline Encouraging investment in tourism infrastructure & 60 & 29 & 8 & 6 & & 4.39 & .866 & .197 \\
\hline Providing job opportunities & 69 & 26 & 4 & 4 & & 4.55 & .751 & .165 \\
\hline Supporting the local economy & 62 & 37 & 2 & 2 & & 4.54 & .638 & .140 \\
\hline $\begin{array}{l}\text { Opening markets for local products and } \\
\text { industries }\end{array}$ & 53 & 40 & 8 & 2 & & 4.40 & .719 & .163 \\
\hline \multicolumn{9}{|l|}{ Social and cultural aspects } \\
\hline Improving services for tourists and locals & 48 & 39 & 12 & 4 & & 4.27 & .819 & .191 \\
\hline Protection of cultural heritage & 66 & 27 & 8 & 2 & & 4.52 & 0.726 & .160 \\
\hline Respect for the local community & 54 & 28 & 19 & - & 2 & 4.30 & .838 & .194 \\
\hline Generational equality & 48 & 30 & 20 & 5 & - & 4.17 & .912 & .218 \\
\hline Encouragement of scientific research & 52 & 28 & 17 & 6 & - & 4.22 & .928 & .219 \\
\hline $\begin{array}{l}\text { Stakeholder participation in the decision-making } \\
\text { process }\end{array}$ & 46 & 41 & 10 & 4 & 2 & 4.21 & .914 & .217 \\
\hline \multicolumn{9}{|l|}{ Environmental aspects } \\
\hline Protect and improve natural diversity & 38 & 36 & 23 & 6 & - & 4.03 & .912 & .226 \\
\hline $\begin{array}{l}\text { Integration of tourism with environmental } \\
\text { planning }\end{array}$ & 34 & 49 & 10 & 8 & 2 & 4.02 & .960 & .238 \\
\hline Reducing excessive energy consumption & 52 & 30 & 13 & 6 & 2 & 4.20 & 1.004 & .239 \\
\hline Respect the environmental borders & 53 & 24 & 18 & 2 & 6 & 4.13 & 1.135 & .274 \\
\hline $\begin{array}{l}\text { Increasing knowledge about biological and } \\
\text { cultural diversity }\end{array}$ & 52 & 32 & 17 & - & 2 & 4.28 & .879 & .205 \\
\hline
\end{tabular}

Table (5) indicates the benefits of achieving a sustainable tourism development in the region by using the GEM as a Tourism route to the Memphite Necropolis. The views of the respondents strongly agree that the application of sustainable tourism and the use of the GEM as the beginning of a Tourism route for the region will achieve many of the economic benefits. These benefits are represented in the following (diversification of income sources, encouraging investment in the tourist infrastructure, providing job opportunities, supporting the local economy and opening markets for local products and industries) with an average arithmetic value ranging between (4.37-4.55) and a standard deviation whose value lies between (638 .- 0.866). 
The values of the standard deviation and the coefficient of variation indicate that there is no dispersion in the data because it is less than half of the mean value. The views of the study sample also indicate many respondents are strongly agreeing about the importance of achieving the sustainable tourism, as it will bring many benefits in the social and cultural aspects. The main benefits, according to the study, can be concluded by improving the provided services for tourists and the local population, protecting cultural heritage, respecting the local community, having a generational equality, encouraging scientific research, as well as participating of stakeholders in the decision-making process with an arithmetic mean whose value falls between (4.17 -4.52). Therefore, the values of the standard deviation and the coefficient of variation indicate that there is no dispersion in the data because it is less than half of the mean value.

The respondents introduced their point of views about the benefits that would be achieved by the sustainable tourism for the environment which are protecting and improving the natural diversity, integrating tourism with environmental planning, reducing excessive energy consumption, and respecting the environmental borders. This is with an average arithmetic (4.02-4.20) and a standard deviation (0.912-0.1135) and indicates values of deviation. Therefore, the values of the standard deviation and the coefficient of variation indicate that there is no dispersion in the data because it is less than half of the mean value. The respondents strongly agree to increase knowledge about biological and cultural diversity with an arithmetic average of 4.28 and a standard deviation of 0.879 .

Table (6): to the obstacles facing achieving tourism sustainability in the Memphite Necropolis.

\begin{tabular}{|l|c|c|c|c|c|c|c|c|}
\hline \multicolumn{1}{|c|}{ Item } & $\mathrm{SA}$ & $\mathrm{A}$ & $\mathrm{N}$ & $\mathrm{D}$ & $\mathrm{SD}$ & Mean & $\begin{array}{c}\text { Std. } \\
\text { Deviation }\end{array}$ & $\begin{array}{c}\text { Coefficient of } \\
\text { variation c.v\%. }\end{array}$ \\
\hline $\begin{array}{l}\text { Lack of awareness and education for } \\
\text { the local population }\end{array}$ & 44 & 49 & 8 & - & 2 & 4.29 & .775 & .180 \\
\hline Exploitation of tourists & 51 & 37 & 2 & 6 & 7 & 4.16 & 1.16 & .282 \\
\hline Lack of tourism services & 38 & $\leq 9$ & 8 & 6 & 2 & 4.12 & .912 & .223 \\
\hline Lack of information about the region & 32 & 45 & 16 & 6 & 4 & 3.92 & 1.02 & .261 \\
\hline $\begin{array}{l}\text { non-preservation of the environment } \\
\text { and the spread of pollution }\end{array}$ & 37 & 55 & 6 & 3 & 2 & 4.18 & .825 & .197 \\
\hline $\begin{array}{l}\text { Lack of good marketing and } \\
\text { promotion of natural reserves and } \\
\text { handicrafts in the region }\end{array}$ & 39 & 49 & 11 & 2 & 2 & 4.17 & .845 & .202 \\
\hline $\begin{array}{l}\text { Lack of training. about the principles } \\
\text { of sustainability }\end{array}$ & 45 & 49 & 6 & 1 & 2 & 4.30 & .790 & .183 \\
\hline
\end{tabular}

Table (6) shows that there are many obstacles facing the achievement of tourism sustainability in the region of the Memphite Necropolis. The views of the respondents indicate that there are many obstacles that prevent the application of the principles of sustainability which are the lack of awareness and education of the local population, the exploitation of tourists and the lack of tourism services. There are also other obstacles such as the lack of tourism services, lack of information about the region, lack of environmental preservation, widespread pollution phenomenon, deficiency in marketing and good promotion of natural reserves and handicrafts in the region with an arithmetic average whose value ranges between (3.92-4.18). Given the values of the standard deviation and the difference coefficient, we note that all of them are less than half of the arithmetic mean values and this indicates no data dispersion. Its value falls between $(0.825-1.16)$ and it is strongly agreed that there is insufficient training in sustainability principles with an average arithmetic value of 4.30 and a standard deviation of 0.790 .

Analyzing the correlation coefficient between the study variables.

Table (7): correlation coefficient (Pearson) between the study variables. 


\begin{tabular}{|c|c|c|c|c|}
\hline & & A & B & $\mathrm{C}$ \\
\hline \multirow{3}{*}{$\begin{array}{l}\text { Availability of the requirements to achieve } \\
\text { sustainable tourism development at the } \\
\text { area of Memphite Necropolis (A) }\end{array}$} & Pearson Correlation & 1 & .193 & $1.000^{* *}$ \\
\hline & Sig. (2-tailed) & & .001 & .000 \\
\hline & $\mathrm{N}$ & 103 & 103 & 103 \\
\hline \multirow{3}{*}{$\begin{array}{l}\text { Benefits would be achieved by sustainable } \\
\text { tourism development at the area of } \\
\text { Memphite Necropolis (B) }\end{array}$} & Pearson Correlation & .193 & 1 & 193 \\
\hline & Sig. (2-tailed) & .001 & & .001 \\
\hline & $\mathrm{N}$ & 103 & 103 & 103 \\
\hline \multirow{3}{*}{$\begin{array}{l}\text { Benefits achieved by sustainable tourism } \\
\text { development at the area of Memphite } \\
\text { Necropolis (C) }\end{array}$} & Pearson Correlation & $1.000^{* *}$ & .193 & 1 \\
\hline & Sig. (2-tailed) & .000 & .001 & \\
\hline & $\mathrm{N}$ & 103 & 103 & 103 \\
\hline
\end{tabular}

It is clear from the analysis of the correlation coefficient between the study variables as there is a direct relationship between the obstacles limiting the achievement of the requirements of sustainable tourism development in the Memphite Necropolis and the application of sustainable tourism requirements themselves with a correlation coefficient of $* * 1.000$ and a level of significance level less than 0.05 , as it is clear that there is a direct relationship between the availability of requirements to achieve sustainable tourism development with the necropolis of Memphis, will achieve many different benefits for the region with a correlation coefficient of value of 193 with a level of significance level less than 0.05 .

\section{Results}

Finally, we concluded the results of proposals for implementing and developing sustainable tourism in the region. The opinions of the sample, $99 \%$ of the respondents indicated that there are many proposals to implement the sustainable tourism in the region, namely: -

- Connecting the GEM with the Memphite Necropolis and using the museum as the beginning of a tourism route that explains the historical background and development of the archeological sites of the Necropolis.

- The GEM potentials has to affect the neighboring sites and the whole Egypt in creating a new destination for the greatest museum for a single civilisation on the world.

- Solving all the problems facing the achieving of the sustainable tourism in the region.

- Providing tourist services in the region, including accommodations, restaurants, bazaars, and visitor centers in the region.

- Promoting local industries and products in the region and preserving them from extinction.

- Encouraging sustainable marketing policies and keeping the local environmental products safe in the region.

- Raising awareness and education about the importance of preserving the environment as an essential element in the sustainable development process.

- Preserving the absorptive capacity of the visiting areas in the region and not misusing the tourists and maintaining the tourist's satisfaction with the offered product.

- Increasing awareness and education of the local people and workers on the importance of sustainable tourism and the extent of its contribution to increasing national income and hard currency.

- Participation of the local community in the sustainable development process as it is one of the sustainable tourism cornerstones.

- Encouraging the sustainable environmental management responsible for the region. 


\section{Recommendation:}

1. It is of crucial importance and immediate priority to develop the neighboring sites of GEM and more precisely the strip of 30 kilometers from Abu Rawash to Dahshur. Prioritising and completing all the missing services and facilities shall help in maintaining a sustainable tourism through the different sites. The careful planning for the future of the GEM and its nearby area is a vital mean of touristic sustainability.

2. Beside all the intended activity programs of GEM, other activity programs (cultural and sportive for instance) can be added in order to link the museum with the neighboring sites.

3. Development of marketing plans for tourism itineraries with a focus on the GEM and the Memphite Necropolis (the area from Abu Rawash to Dahshur).

4. Development of facilities along the route leading to the archaeological site.

5. For generating a sustainable tourism and maximizing the income from GEM complex and the neighboring archaeological sites different procedures have to be taken such as: making memberships for the GEM and its neighboring archeological sites, providing VIP support, finding sponsorship for the GEM brand, marketing and promoting the whole region, making charter flights and creating international huge annual events.

6. Different suggested itineraries have to be created such as this 3 days itinerary at the region of the Memphite Necropolis:

\begin{tabular}{|c|c|c|}
\hline \multicolumn{3}{|c|}{ Itinerary of visiting GEM with Memphite Necropolis } \\
\hline Time & Events & Notes \\
\hline \multicolumn{3}{|c|}{ First Day } \\
\hline $8: 00_{\mathrm{am}}-9: 00 \mathrm{am}$ & Breakfast at hotel & $\begin{array}{l}\text { New hotels near GEM have to be constructed with } \\
\text { the names of Khufu, Khafra and Menkawra for } \\
\text { example which would be beautiful eternal } \\
\text { memories for the tourists. }\end{array}$ \\
\hline $9: 00_{\mathrm{am}}-5: 00 \mathrm{pm}$ & $\begin{array}{l}\text { Visiting GEM then ancient Memphis } \\
\text { capital city }\end{array}$ & Lunch in GEM Restaurants \\
\hline \multicolumn{3}{|c|}{ Second Day } \\
\hline $8: 00_{\mathrm{am}}-9: 00_{\mathrm{am}}$ & Breakfast at hotel & \\
\hline $9: 00-5: 00 \mathrm{pm}$ & Visiting Saqqara then Dahshur & $\begin{array}{ll} & \text { At Saqqara school of carpets } \\
\text { - } & \text { traditional local Lunch at Dahshur } \\
\text { - } & \text { Program includes the new tourist visitor } \\
& \text { center, seasonal lake of Dahshur, New Crafts } \\
& \text { Heritage associations and Harraniya Village. }\end{array}$ \\
\hline \multicolumn{3}{|r|}{ 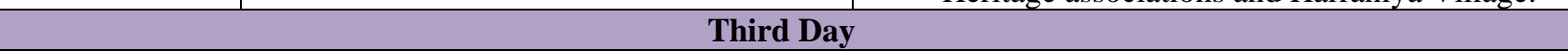 } \\
\hline $8: 00_{\mathrm{am}}-9: 00_{\mathrm{am}}$ & Breakfast at hotel & \\
\hline $9: 00_{\mathrm{am}}-5: 00 \mathrm{pm}$ & $\begin{array}{ll}- & \text { Great pyramids of Giza } \\
- & \text { the lost pyramid of Abu Rawash } \\
- & \text { pyramids of the forgotten kings at } \\
\text { Abusir }\end{array}$ & $\begin{array}{l}\text { - The program includes El Hassana Dome } \\
\text { Protectorate at Abu-Rawash } \\
\text { - Traditional Local Lunch at Abu Rawash }\end{array}$ \\
\hline
\end{tabular}


International Journal of Heritage, Tourism and Hospitality Vol. (14), No. (3) Spsecial Issue

\section{Map of Each Day}

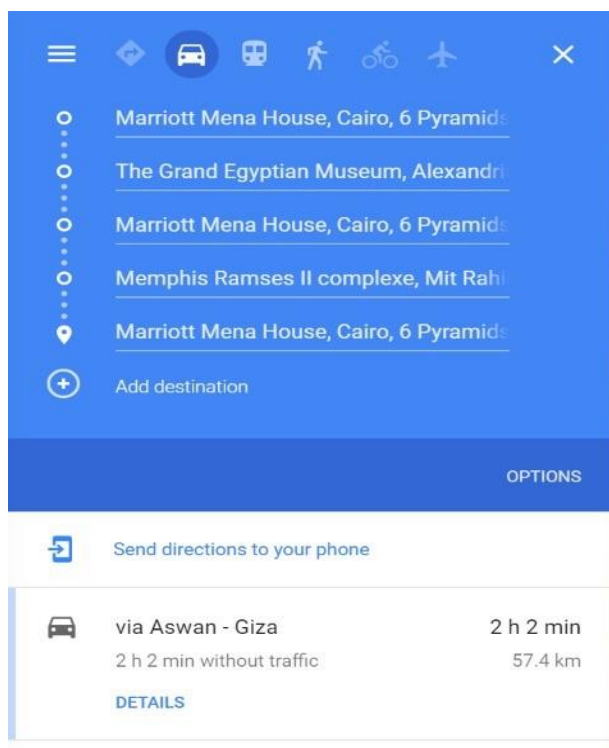

Explore Marriott Mena House, Cairo

Fig. 1: First Day

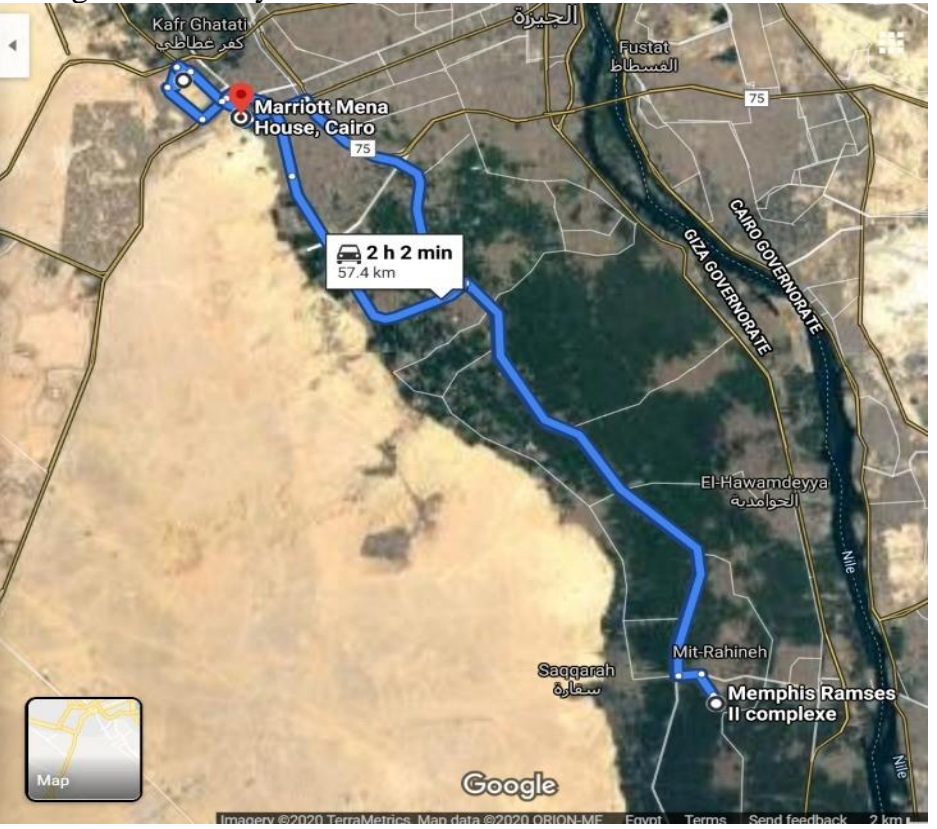

Fig. 2: Second Day

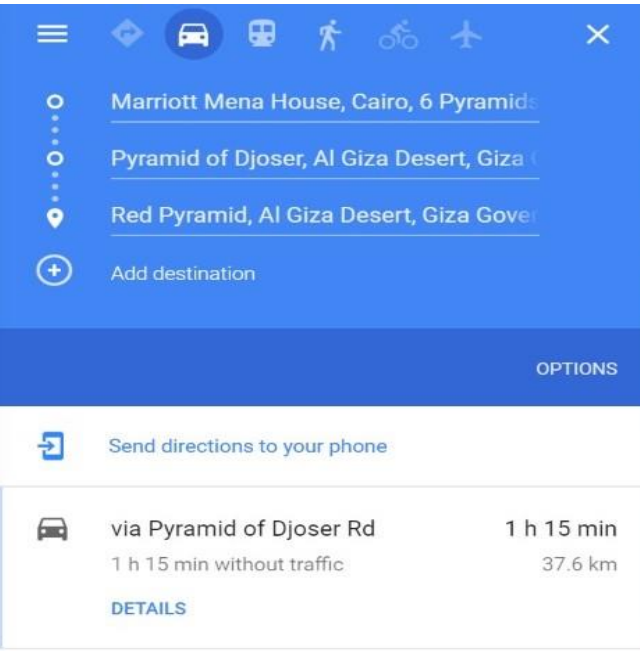

Explore Red Pyramid
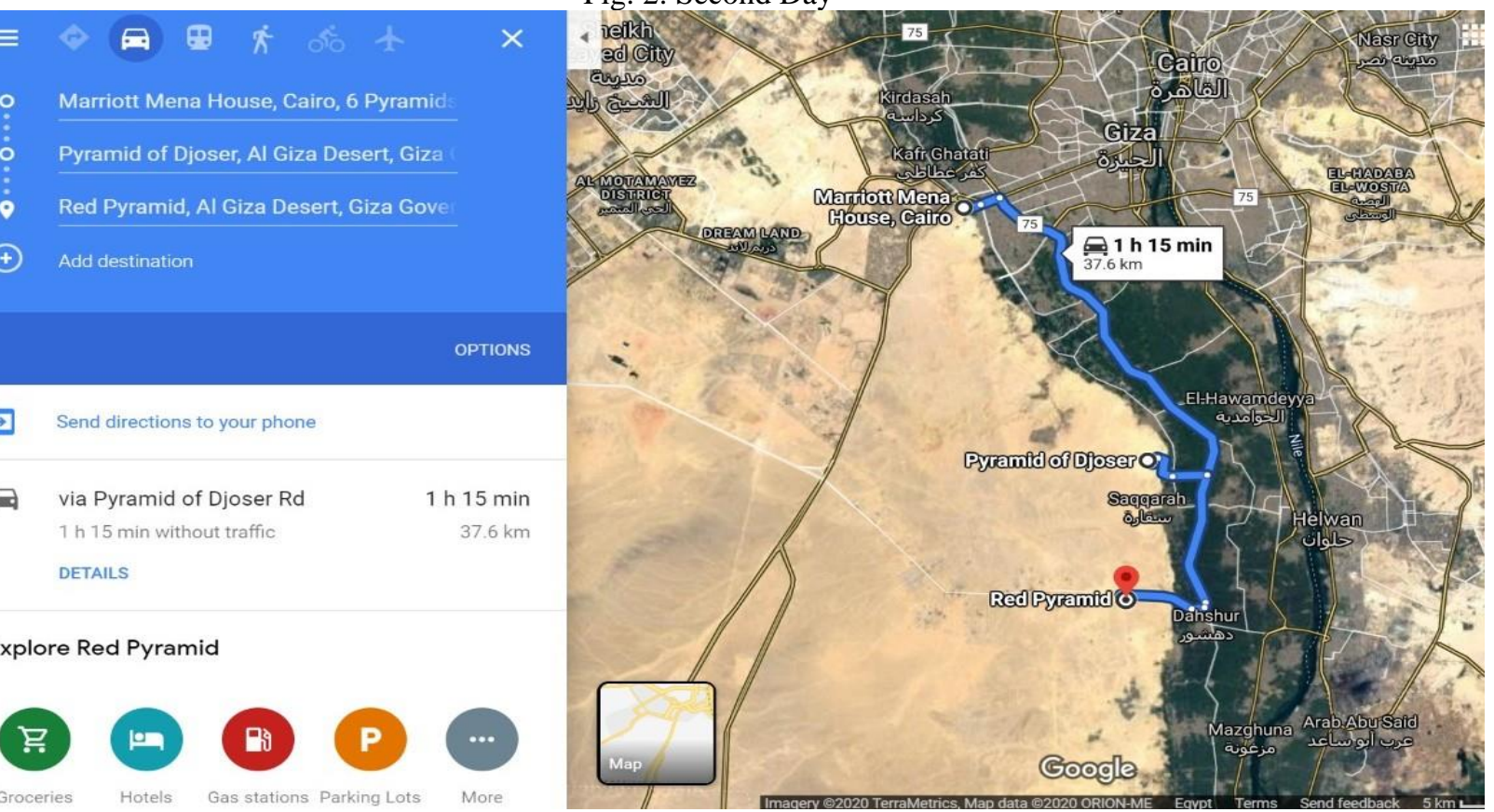
International Journal of Heritage, Tourism and Hospitality Vol. (14), No. (3) Spsecial Issue

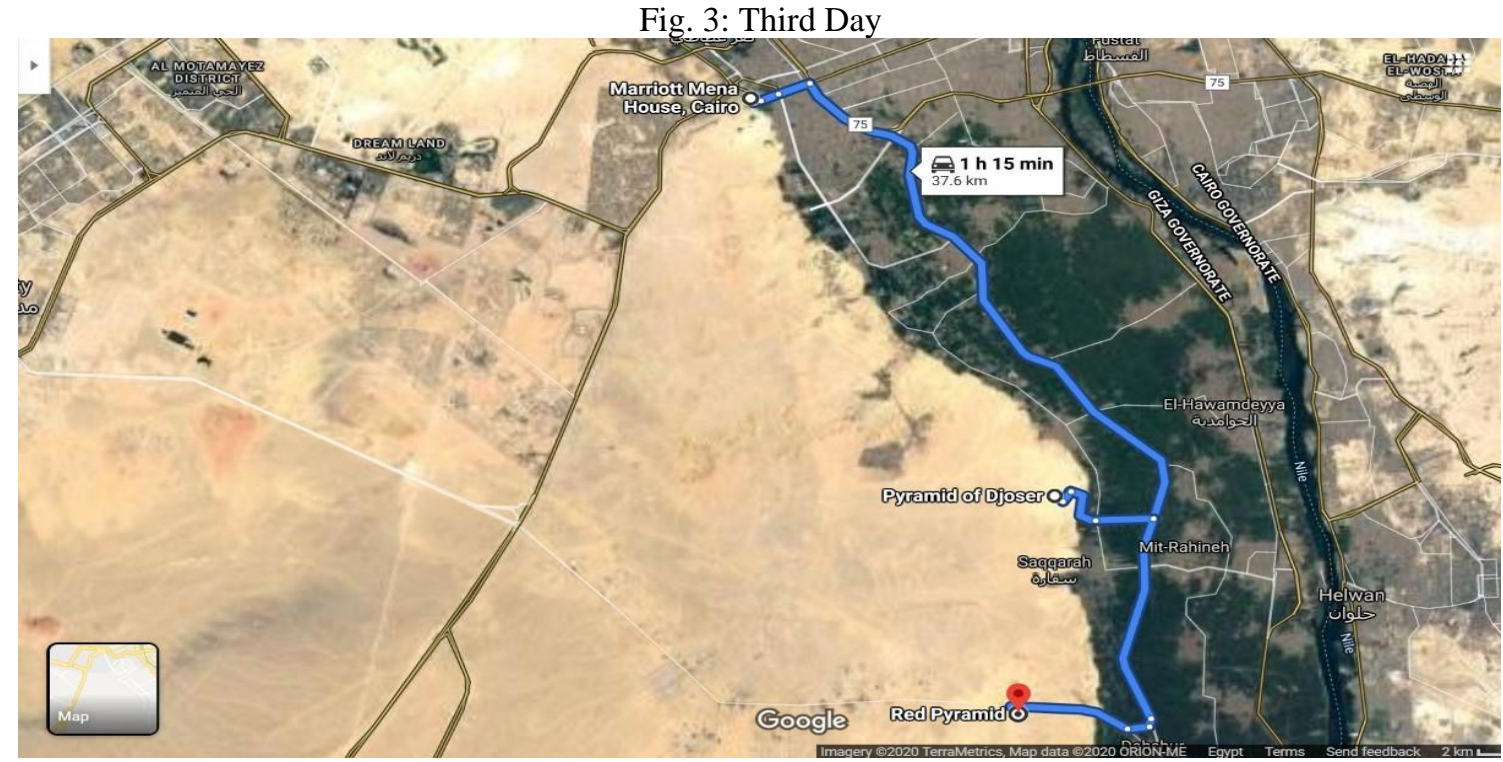

Fig. 4: GEM and Giza plateau a part of the Memphis Necropolis.

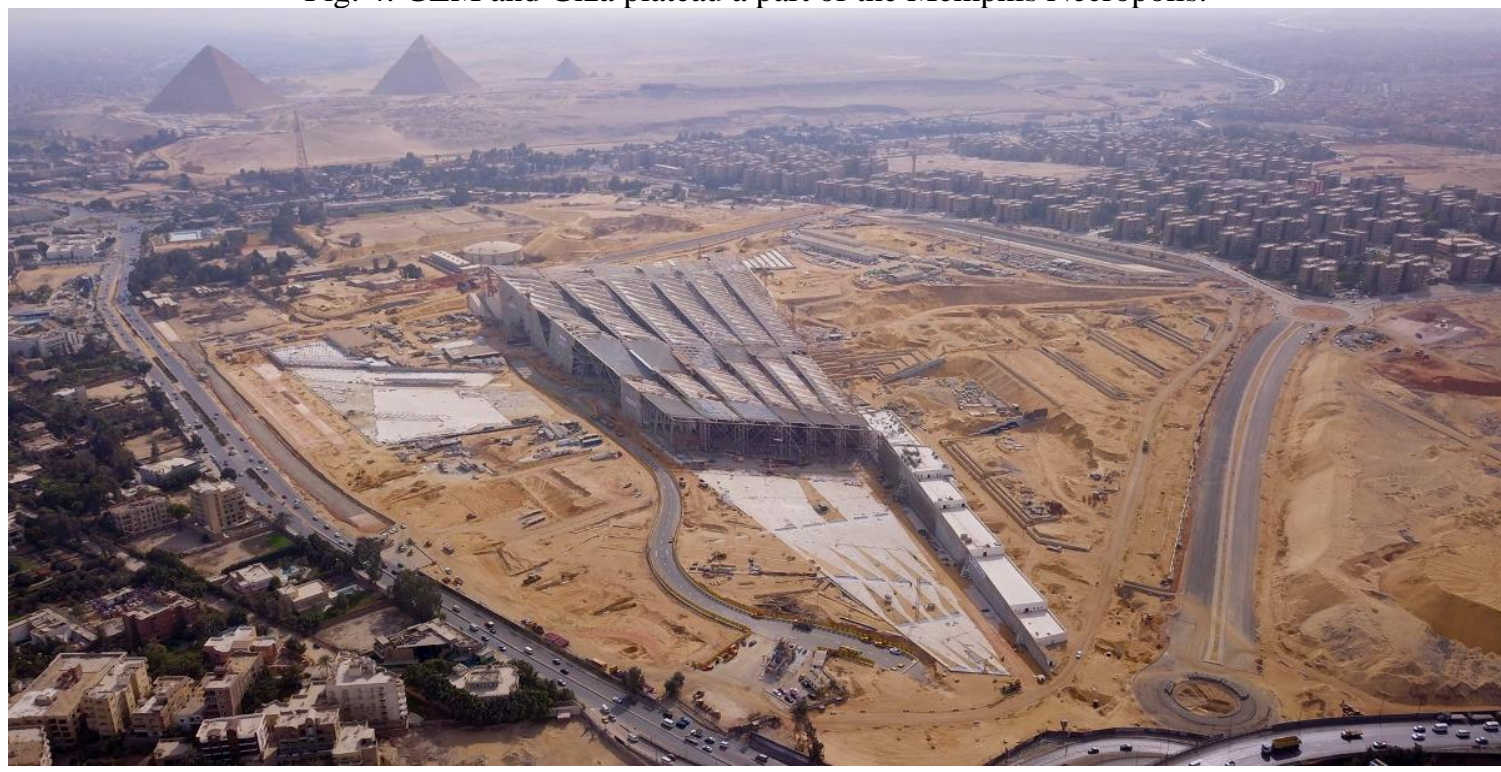

Fig 5: The Grand Museum Façade

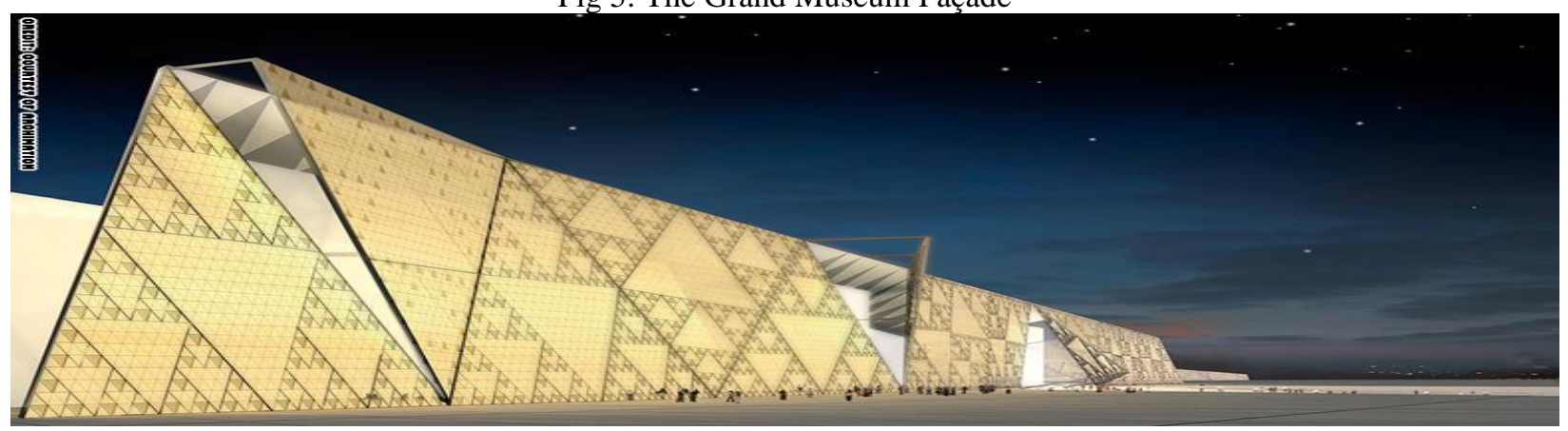




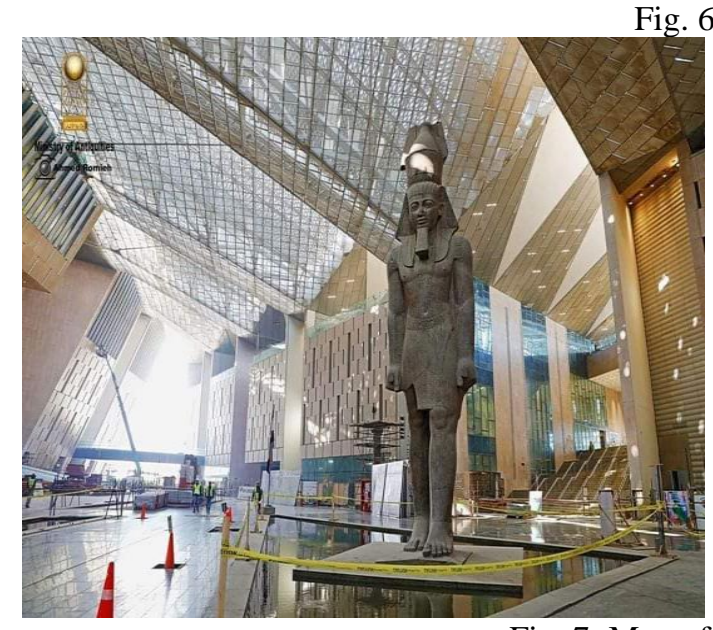

Fig. 6: GEM galleries

Fig. 7: Map of the Memphis Necropolis

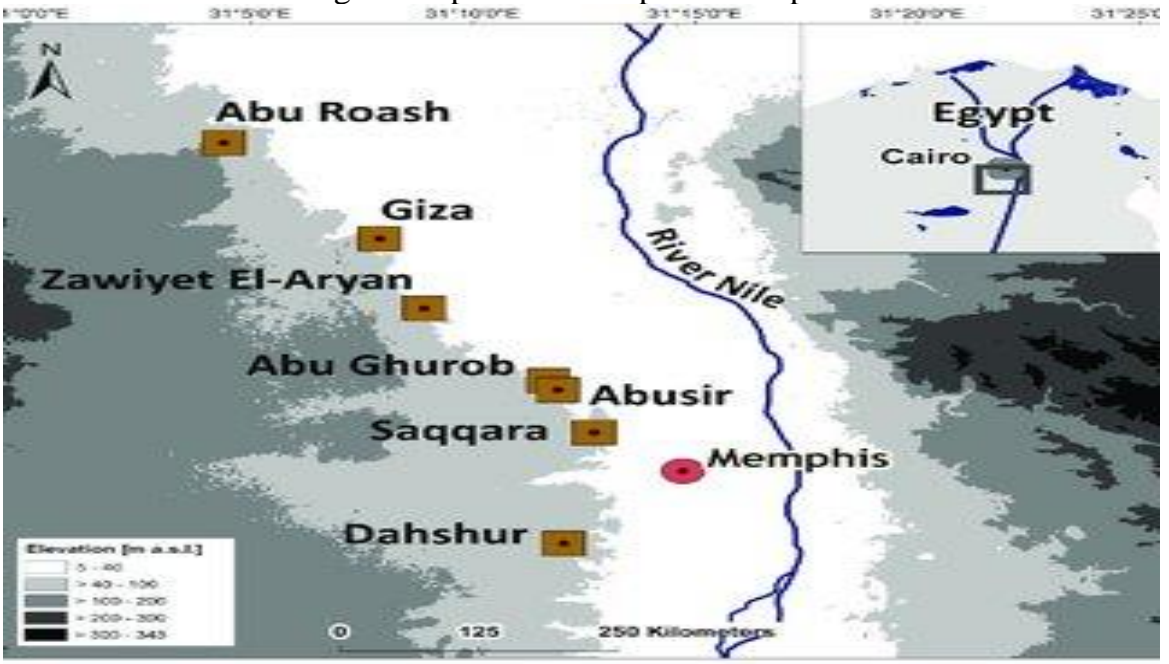

Fig. 8: Main pyramids at Saqqara \& Dahshur in Memphis Necropolis
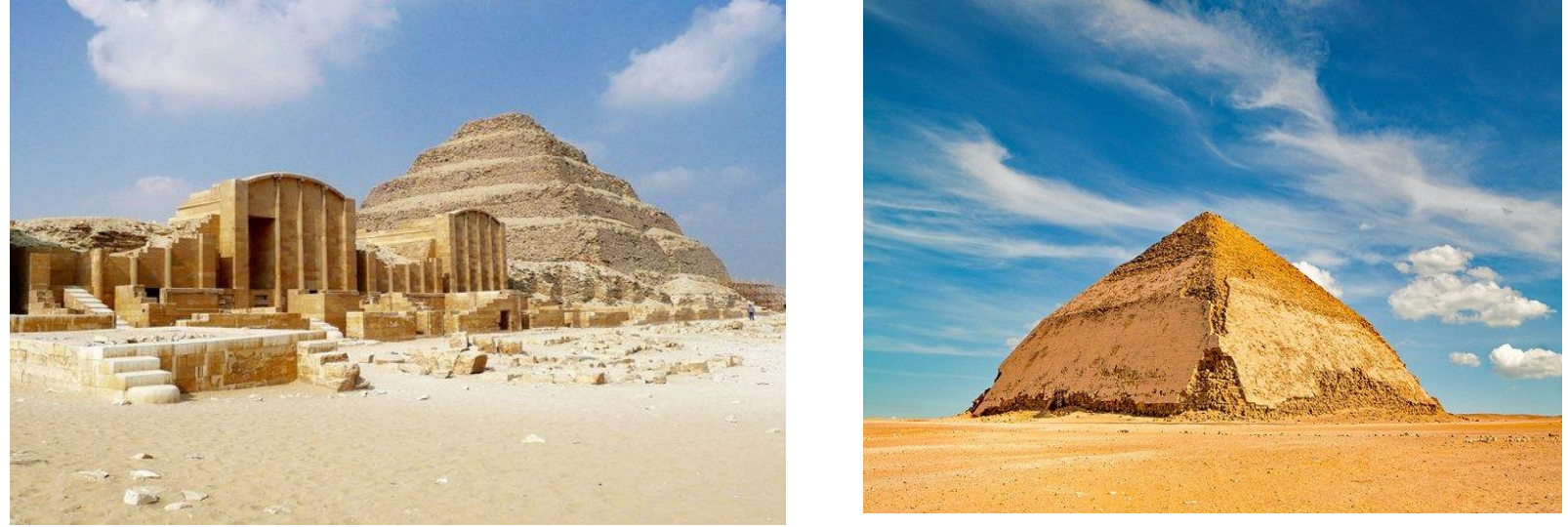

\section{Bibliography}

Andreu-Lanoe G., Egypt in the Age of the Pyramids, trans. From French by David Lorton, new York: Cornell university press 1997.

David D. Peck, Voyage without a Harbor, iUniverse, 2014.

Edwards I. E. S., The Pyramids of Egypt, Penguin Books, 1993. 
El-Shahawy, A., \& Matḥaf al-Mișri, M., The Egyptian Museum in Cairo, American Univ in Cairo Press, 2005.

Elweshahy M., \& ElGammal, I., Sustainable Tourism Planning in the Area of Abusir, JAAUTH vol 9 (special issue). 2012

Fagan, M.B., The Oxford Companion to Archaeology, New York : Oxford University Press, 2012.

Hellum, J. E., The Pyramids, Greenwood Press, 2007.

John J. Pigram, Wahab, s., Tourism, Development and Growth: The Challenge of Sustainability, Routledge, 2005.

Jenkins, N., The boat beneath the pyramid: King Cheops' royal ship, Holt, Rinehart and Winston, 1980.

Lauer J. Ph., Saqqara: the royal cemetery of Memphis : excavations and discoveries since 1850, London: Thames and Hudson, 1976.

River, C., Saqqara: The History and Legacy of the Ancient Egyptian Necropolis Near Memphis, CreateSpace Independent Publishing Platform, 2018.

Robins, G., The Art of Ancient Egypt, Harvard University Press, 2008.

Shaw, I., The Oxford History of Ancient Egypt, Oxford University Press: Oxford, 2000.

Shaw, I. \& Nicholson P., A British Museum Dictionary of Ancient Egypt, London: 1995.

Timothy, D.J. \& Boyd, S.W, Tourism and Trails: Cultural, Ecological and Management Issues, Channel View Publications, 2015.

Tolvanen, A. Rämet. J. Kinnunen, I. \& others, Sustainable Tourism, Finnish Forest Research Institute, Muhos Research Station, Kirkkosaarentie 7, FIN-91500 Muhos, Finland. 2005.

UNESCO publications, "World Heritage Sites: A Complete Guide to 878 UNESCO World Heritage Sites", Firefly Books, 2009.

Verner, M., The pyramids, Atlantic Books Ltd, 2014.

Verner, M., The Pyramids: The Mystery, Culture, and Science of Egypt's Great Monuments, Grove Press. 2001.

Ward-Perkins, D., Beckmann, C. \& Ellis, J., Tourism Routes and Trails: Theory and Practice, CABI, 2019.

Yazdi, Khoshnevis S., "Sustainable Tourism" in American International Journal of Social Science Vol. 1 No 1, 2012.

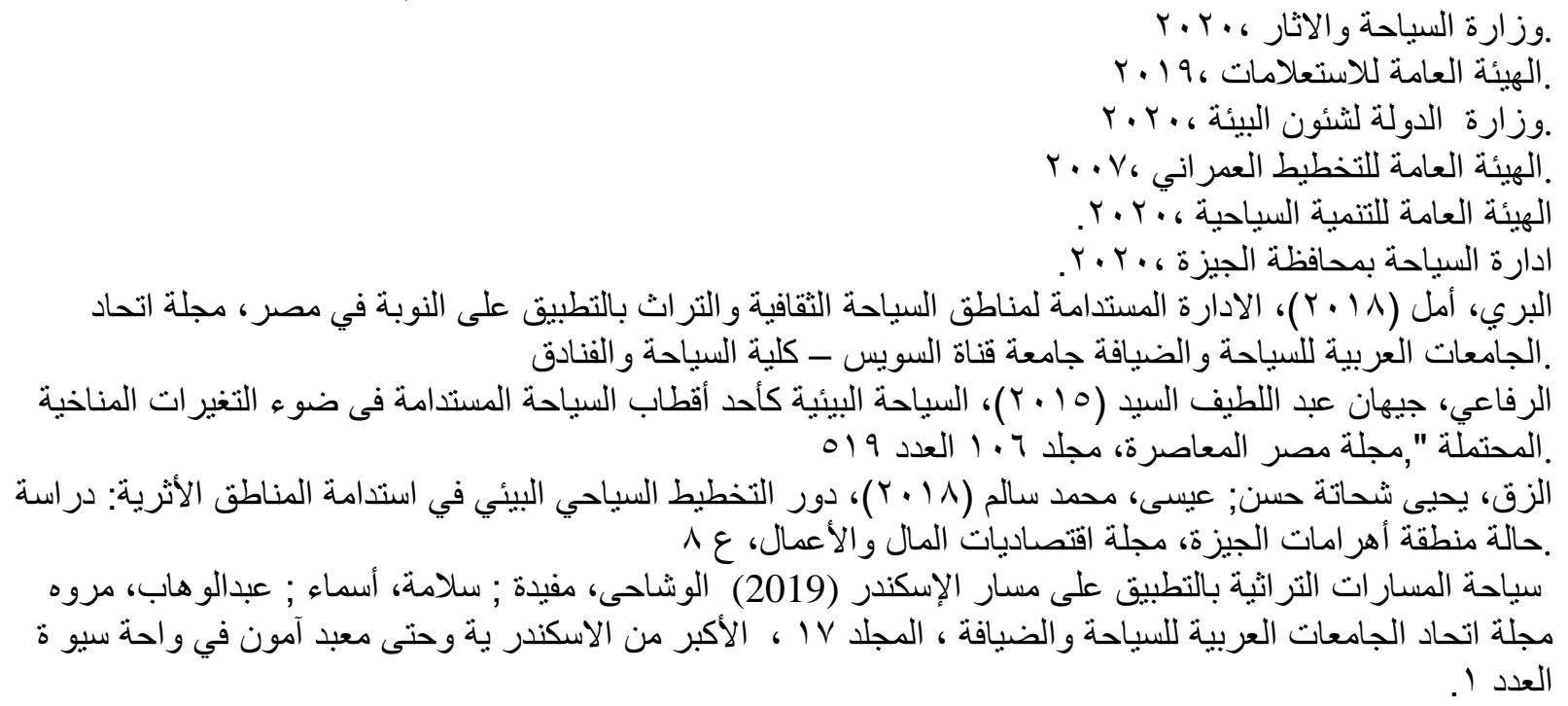




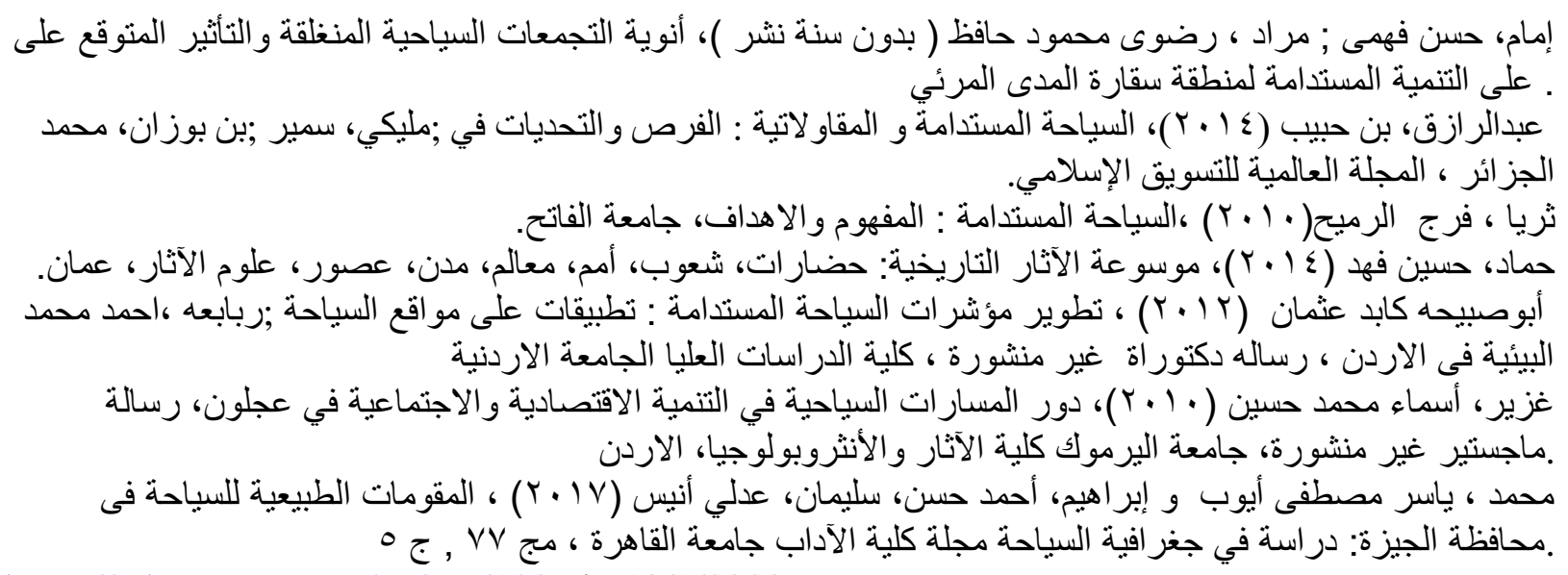
https://whc.unesco.org/en/soc/1809 in 10/1/2020. http://www.antiquities.gov.eg/DefaultAr/WorldHeritageSite/Pages/WorldHeritage.aspx ?World HeritageCode $=7$ in 20/2/2020. https://www.mq.edu.au/research-impact/2014/09/04/the-earliest-funerary-boat-ever-found/ in $15 / 2 / 2020$.

http://www.tda.gov.eg/TdaRegions/EgyMap.aspx. accessed on 3/2020 